\title{
PENINGKATAN KREATIVITAS ANAK \\ MELALUI PEMBELAJARAN MENEMPEL PADA ANAK KELOMPOK B-3 \\ TK NEGERI PEMBINA KOTA YOGYAKARTA TAHUN 2015
}

Oleh:

Titi Nugraini,

Guru TK Negeri Pembina Yogyakarta

tnugraini@gmail.com

\begin{abstract}
Abstrak
Penelitian ini bertujuan untuk meningkatkan kreativitas anak Taman Kanak-Kanak dengan harapan akan berdampak pada optimalisasi perkembangan kognitif anak.Penelitian ini merupakan Penelitian Tindakan Kelas yang dilaksanakan dengan pendekatan kualitatif. Desain penelitian merupakan penelitian berulang sesuai siklus spiral sebagaimana mengikuti pendapat Kemmis dan Me. Taggart. Penelitian dilaksanakan di Kelompok B-3 TK Negeri Pembina Yogyakarta pada semester genap Tahun Pelajaran 2014/2015 dengan jumlah 16 anak. Pengumpulan data dilakukan dengan menggunakan instrumen lembar observasi dan anekdote record. Berdasarkan analisis deskriptif, penelitian ini menunjukkan hasil bahwa pembelajaran menempel kepingan bentuk-bentuk geometri telah terbukti dapat meningkatkan kreativitas anak TK. Berdasarkan data hasil observasi diperoleh data bahwa sebelum dilakukan tindakan ada $25 \%$ anak yang berkembang sesuai harapan dan ada $75 \%$ anak yang mulai berkembang. Setelah dilakukan tindakan pada siklus I diperoleh peningkatan data ada $56 \%$ anak mulai berkembang dan $44 \%$ anak berkembang sesuai harapan, siklus II ada 36\% anak mulai berkembang dan $64 \%$ anak berkembang sesuai harapan, siklus III diperoleh ada $7 \%$ anak mulai berkembang dan $82 \%$ anak berkembang sesuai harapan serta ada $11 \%$ anak berkembang sangat baik. Dapat disimpulkan bahwa pembelajaran menempel kepingan bentuk-bentuk geometri dapat meningkatkan kreativitas anak TK di Kelompok B-3 TK Negeri Pembina.
\end{abstract}

Kata kunci: Kreativitas, Menempel, Bentuk - bentuk geometri

\begin{abstract}
The research is aimed at improving kindergarten students' creativity to optimize their cognitive development. The classroom action research was done using qualitative approach. The research design used repeated spiral cycle as what Kemmis and McTaggart proposed. The research was conducted in group B-3 TK Negeri Pembina Yogyakarta during the even semester in the 2014/2015 academic year involving 16 students. The data was obtained using field note and anecdote record. Based on the descriptive analysis, the research result proved that sticking pieces of geometric shape learning can improve the creativity of the kindergarten students. From the observation data, before the treatment there were only 25\% of the students develop into expected progress result and there were $75 \%$ students started to make progress. After the treatment, in cycle I there was an increase of result showing 44\% students develop as expected and 56\% students are still in progress; in cycle II there were 64\% students develop as expected and 36\% students are still in progress; in cycle III there were $82 \%$ students develop as expected, $7 \%$ students are still in progress, and $11 \%$ students develop very well. It can be concluded that the sticking pieces of geometric shape learning can increase the creativity of kindergarten students in group B-3 TK Negeri Pembina.
\end{abstract}

Keywords: creativity, sticking, geometric shape 


\section{PENDAHULUAN}

Perkembangan kognitif anak menekankan bagaimana pikiran anak berkembang dan berfungsi sehingga anak dapat berfikir secara runtut, dapat mengembangkan ide-ide baru. Semua anak memiliki perkembangan kognitif yang sama yang meliputi tahap sensori motor (0-2 th) yaitu anak banyak menggunakan gerak reflek dan inderanya untuk berinteraksi dengan lingkungan, kemudian tahap pre operasional (2-7 tahun) yaitu anak mulai mengenali beberapa simbol dan tanda sehingga dalam kegiatan pembelajaran harus memakai media karena anak masih berpikir kongkrit, kemudian tahap kongkret operasional (7-11 tahun) yaitu anak sudah dapat memecahkan masalah sederhana yang bersifat kongkrit serta dapat berpikir reversible yaitu anak dapat memahami suatu pernyataan, dan tahap formal operasional (11 tahun ke atas) yaitu anak dapat berpikir secara abstrak serta dapat berpikir secara hipotetik dan deduktif.

Mengingat pendidikan yang diberikan pada anak usia dini sangat berpengaruh pada keberhasilan pendidikan pada tahap selanjutnya, maka menjadi penting untuk menanamkan perilaku berpikir dan bertindak kreatif pada anak sebagai upaya pembentukan karakter dan kepribadian anak. Mengingat kreativitas merupakan puncak dari kemampuan seseorang dalam berpikir, maka penting sekali menumbuhkan sikap kreatif pada anak sejak usia Taman Kanak-Kanak. Sikap kreatif yang menjadi kepribadian dan kebiasaan anak sejak dini akan membekali anak untuk mampu menyelesaikan berbagai persoalan hidup yang dihadapi anak dalam kehidupan selanjutnya. Kreativitas yang ada pada diri anak akan membuat anak menjadi survive, bertahan hidup, dan menjadi eksis.

Berfikir kreatif berarti bernalar dengan mengembangkan daya cipta, mengurai ide-ide, serta memecahkan masalah (problem solving).
Mengembangkan sikap kreatif anak di lembaga pendidikan bukanlah perkara gampang, karena kreativitas tidak begitu disukai karena kerap berbeda dengan keinginan guru. Anak yang memiliki kreativitas tinggi sering mencari jalan keluar dari permasalahan yang dihadapi dengan caranya sendiri, keluar dari pakem dan keumuman.

Menjadi pribadi yang kreatif sangat ditentukan oleh faktor internal dan eksternal anak. Faktor internal anak yang memiliki semangat dan kemauan untuk berpikir dan bertindak kreatif sangat memegang peranan penting, karena dengan kemauan yang ada pada diri anak untuk bersikap dan bertindak kreatif akan menjadi energi yang luar biasa bagi anak. Anak akan melakukan berbagai upaya untuk senantiasa memecahkan persoalan yang dihadapi dengan caranya sendiri. Namun demikian, faktor eksternal juga tidak kalah penting. Kondisi lingkungan dalam keluarga, masyarakat dan sekolah yang mendukunng anak untuk mengembangkan kreativitasnya sangat berpengaruh pada perkembangan anak. Peran pendidik diketiga lingkungan tersebut memegang peran yang sangat menentukan, sehingga harus saling bersinergi dengan harapan ada kesinambungan dalam memberikan pendidikan bagi anak.

Berdasarkan pengamatan yang dilakukan pada anak-anak Kelompok B-3 TK Negeri Pembina yang berjumlah 16 anak, diperoleh data bahwa sebagian besar anak-anak lebih banyak yang kurang berinisiatif dan bersikap menunggu, kurang memiliki rasa tanggung jawab terhadap tugasnya, kurang rapi dalam menyelesaikan tugasnya, kurang mandiri, kurang bangga atas hasil karyanya.

Sikap kurang kreatif anak Kelompok B-3 TK Negeri Pembina terlihat pada saat anak mengerjakan satu tugas, belum berani untuk menuangkan idenya, cenderung menunggu perintah guru, tidak berani berbeda dengan 
temannya ataupun gurunya, takut salah sehingga berdampak pada hasil karyanya yang kurang maksimal.

Sikap kurang bertanggungjawab ditunjukkan anak dengan kurang semangat dalam menyelesaikan tugas, lebih sering berbicara dengan temannya sehingga tugasnya lama terselesaikan, mengerjakan tugasnya asal jadi tanpa mempertimbangkan segi estetika atas karyanya karena ingin segera bermain.

Sikap kurang mandiri terlihat pada saat anak mengerjakan tugas dari guru sering minta bantuan guru atau temannya, sering bertanya dan minta pendapat pada guru pada saat akan mengerjakan tugas, ragu-ragu dalam bertindak, kurang percaya diri, senang meniru yang dilakukan temannya. Sikap anak yang kurang mengapresiasi hasil karyanya terlihat pada saat dinilai hasil karya anak cenderung bersikap malu-malu.

Upaya untuk mengatasi permasalahan yang ada di kelas ini, penting kiranya untuk mencoba membimbing anak agar mampu mengembangkan kreativitasnya, mampu menuangkan ide anak, melatih sikap tanggung jawab anak dengan mengarahkan anak agar menyesaikan tugasnya dengan baik, menumbuhkan sikap kemandirian anak, serta menumbuhkan anak agar bangga dengan karya yang dihasilkan anak.

Kegiatan pembelajaran menempel kepingan bentuk-bentuk geometri menjadi salah satu pilihan yang dapat membantu meningkatkan kreativitas anak -anak, mengingat kegiatan menempel bentukbentuk geometri menjadi bentuk tertentu yang bermakna merupakan kegiatan yang menyenangkan bagi anak serta cukup memiliki tingkat kesulitan, yang merupakan tantangan tersendiri bagi anak.

Melihat latar belakang masalah tersebut, dapat dirumuskan permasalahan yang ada diantaranya adalah :

1. Bagaimana meningkatkan kreativitas anak Kelompok B-3 TK Negeri Pembina melalui pembelajaran menempel kepingan bentuk-bentuk geometri?

2. Apakah kegiatan menempel kepingan bentuk-bentuk geometri mampu meningkatkan kreativitas anak Kelompok B-3 TK Negeri Pembina?

Penelitian tindakan kelas melalui kegiatan menempel kepingan bentukbentuk geometri ini bertujuan untuk :

1. Meningkatkan kreativitas anak TK Negeri Pembina melalui kegiatan menempel kepingan bentuk-bentuk geometri

2. Menanamkan kepada anak sejak usia TK agar berani menuangkan ide gagasannya

3. Menanamkan kepada anak agar mandiri dalam menyelesaikan tugas

4. Menumbuhkan sikap tanggung jawab atas segala tugas yang harus diselesaikan

5. Menumbuhkan rasa bangga pada diri anak atas segala hasil karyanya

\section{Kreatif}

Kreativitas anak Taman KanakKanak berhubungan erat dengan aspek perkembangan kognitif anak dan merupakan bagian penting dalam perkembangan anak usia dini. Kreativitas anak akan meningkat karena kesadaran kognitif anak yang telah meningkat yang memungkinkan imajinasi dan daya khayal anak lebih berkembang sehingga wawasan anak, daya cipta dan daya pikir anak juga berkembang.

Secara etimologi, kata kreatif berasal dari bahasa inggris "create" yg berarti menciptakan, creation artinya ciptaan. Kreativitas adalah suatu proses yang menghasilkan sesuatu yang baru, apakah suatu gagasan atau suatu objek dalam suatu bentuk atau susunan yang baru (Hurlock, 1978: ). Dapat dipahami bahwa kreativitas merupakan kemampuan seseorang untuk menciptakan atau menghasilkan sesuatu yang baru yang berbeda dari yang telah ada. Untuk dapat 
mengembangkan kreativitas anak, dibutuhkan kemampuan anak untuk berimajinasi agar daya pikirnya berkembang secara maksimal. Kemampuan anak untuk mengembangkan ide/gagasan perlu didorong agar anak memiliki keberanian untk menuangkan idenya. Kreativitas merupakan puncak dari kemampuan dalam berpikir sehingga anak perlu diasah sejak usia dini, perlu ditanamkan bahwa berpikir dan bersikap yang berbeda dengan orang lain merupakan hal yang baik dan wajar.

Kreativitas dirumuskan dan dikaji melalui the four Ps of creativity.

a. Person

Kreativitas merupakan ungkapan unik dari seluruh pribadi sebagai hasil interaksi individu, perasaan, sikap dan perilakunya. Kreativitas mulai dengan kemampuan individu untuk menciptakan sesuatu yang baru. Biasanya seorang individu yang kreatif memiliki sifat yang mandiri. Ia tidak merasa terikat pada nilai-nilai dan norma-norma umum yang berlaku dalam bidang keahliannya.

b. Process

Kreativitas adalah suatu proses upaya manusia untuk membangun dirinya dalam berbagai aspek kehidupannya untuk menikmati kualitas kehidupan yang semakin baik. (Alvian, 1983:). Kretaivitas adalah suatu proses yang tercermin dalam kelancaran, kelenturan (fleksibilitas) dan originalitas dalam berfikir (Utami Munandar, 1977: ).

c. Press

Dukungan dan dorongan dari eksternal sangat berperan dalam mengembangkan sikap kreatif seseorang. Orang - orang dari lingkungan keluarga, sekolah dan masyarakat berperan besar dalam menciptakan lingkungan kondusif untuk menuju ke arah berpikir dan bertindak kreatif.

d. Product

Seseorang dikategorikan bertindak dan bersikap kreatif apabila karya yang diciptakan merupakan karya ciptaan yang baru, asli dan bermakna bagi individu dan atau lingkungannya.

Kreativitas memegang peranan yang sangat penting, karena dengan berbekal kreativitas manusia memecahkan problema hidup dan menjalaninya. Anak yang memiliki kreativitas tinggi akan dapat memecahkan berbagai persoalan yang dihadapinya dengan cara yang berbeda dengan yang biasa dilakukan orang lain. Anak yang kreatif akan berfikir kreatif yang berarti bernalar dengan mengembangkan daya cipta, mengurai ide-ide, serta memecahkan masalah (problem solving). Kreativitas sering mencari jalannya sendiri, keluar dari pakem dan keumuman, menjadi kreatif juga berarti siap menanggung risiko. Membangun budaya kreatif tidak lain adalah membangun sikap yang terbuka dan toleran, bisa menerima ide orang lain. Mengembangkan kreativitas di sekolah bukanlah perkara gampang, karena kreativitas sering berlawanan dengan keinginan guru.

Kreativitas bukanlah bersifat keturunan tetapi kreativitas dapat dipelajari dan dapat ditingkatkan. Adapun faktor yang dapat mendorong anak menjadi kreatif adalah : motivasi intrinsik dan ekstrinsik. Setiap individu memiliki kecenderungan atau dorongan mewujudkan potensinya, mewujudkan dirinya, dorongan berkembang menjadi matang, dorongan mengungkapkan dan mengaktifkan semua kapasitasnya. Dorongan ini merupakan motivasi primer untuk kreatif ketika individu membentuk hubungan-hubungan baru dengan lingkungannya dalam upaya manjadi dirinya sepenuhnya.

Kondisi eksternal juga menjadi faktor pendorong anak untuk dapat bersikap kreatif, karena kretaivitas memang tidak dapat dipaksakan, tetapi harus dimungkinkan untuk tumbuh, mengingat bibit unggul memerlukan kondisi yang dapat memupuk dan 
memungkinkan bibit itu mengembangkan sendiri potensinya.

Dalam meningkatkan sikap kreatif tidaklah mudah, tetapi ada hal-hal yang dapat menghambat anak bisa bersikap kreatif diantaranya adalah :

a. Rasa Takut

Anak yang dalam keadaan takut, sinapsinap dalam otaknya tidak akan berkembang secara baik. Rasa takut akan membuat sikap kritis dan kreatifnya tidak akan muncul. Anak harus dijauhkan dari hal-hal yang membuatnya takut, seperti sikap guru yang terlalu keras, suasana kelas yang tidak kondusif, terjadinya bulliying di sekolah, orang tua yang menerapkan pola asuh cenderung otoriter.

b. Rasa Puas

Kecenderungan anak yang cepat merasa puas atas apa yang telah diusahakannya akan membuat anak tersebut berhenti berbenah dan belajar. Akan tercipta usaha yang gigih pada diri anak untuk melakukan yang terbaik bila guru di kelas dapat berlaku sebagai motivator sehingga mampu membangkitkan daya juang anak.

c. Rutinitas Tinggi

Pola pembelajaran yang monoton dengan tuntutan hasil belajar yang tinggi, akan membuat anak terjebak pada rutinitas yang sebenarnya tidak mendorong anak untuk bersikap kreatif. Inovasi dalam pengelolaan kelas sehingga tercipta kelas yang atraktif, sangat penting sekali untuk diciptakan oleh guru agar dapat menumbuhkan sikap kreatif.

d. Kemalasan Mental

Era sekarang yang serba mudah, tidak spenuhnya baik buat anak. Memberikan pendidikan yang instan, serba cepat, kurang memandirikan anak, akan membentuk anak bermental lemah, mudah menyerah, malas dan memiliki daya juang rendah. Perlu seorang guru yang mampu membimbing anak didik agar memiliki mental baja. e. Birokrasi

Tatanan dalam sekolah yang kaku dan tidak memberi ruang gerak dan ruang berkreasi yang luas, akan menghambat kreativitas anak didik. Penting sekali agar guru leluasa berekspresi dan selalu memahami dan menerapkan quantum theaching sehingga kegiatan pembelajaran tidak terkesan kaku dan formal.

f. Stereotyping

Sikap anak yang selalu ingin sama dengan temannya perlu segera diarahkan sehingga anak tidak memiliki sikap stereotyping. Perbedaan yang ada diantara temannya merupakan sebuah kekayaan yang harus dilestarikan agar tercipta saling menghargai. Apabila hal ini terpupuk dengan baik, akan tercipta harmoni sosial di dalam kelas dan sekolah.

\section{Geometri}

Kata geometri berasal dari Yunani Kuno, geo berarti bumi dan metron berarti pengukuran. Geometri adalah cabang dari matematika yang bersangkutan dengan bentuk, ukuran, posisi serta sifat ruang. Ada berbagai macam bentuk geometri yang dapat dikenalkan kepada anak TK, tetapi penulis mengenalkan bentuk geometri yang berjumlah empat yaitu bentuk segi tiga, lingkaran, segi empat serta persegi panjang.

Mengenalkan bentuk-bentuk geometri seperti bentuk segitiga, segi empat, persegi dan lingkaran bisa dilakukan kepada anak sejak usia dini. Kegiatan pengenalan bentuk-bentuk geometri bisa dilakukan dengan berbagai permainan. Media yang dipergunakan juga disesuaikan dengan kegiatan yang akan di laksanakan. Misalkan dengan kegiatan menggambar bentuk-bentuk geometri, dengan menggunting gambar bentuk geometri, mencocok gambar bentuk geometri, memola gambar bentuk geometri, menempel kepingan bentuk geometri. 
Upaya agar anak-anak sejak dini terbiasa bersikap kreatif, perlu kiranya dirancang kegiatan pembelajaran yang dilakukan secara berbeda dari biasanya. Model pembelajaran menempel kepingan bentuk - bentuk geometri ini memberi kesempatan kepada anak-anak untuk menyelesaikan suatu masalah sesuai keinginannya sehingga anak terbiasa berpikir dan bertindak berbeda dengan temannya, mengembangkan imajinasinya, mengembangkan daya kreativitas anak. Dengan kegiatan pembelajaran menempel kepingan bentuk-bentuk geometri ini diharapkan anak didik dapat meningkat kreativitasnya. Tentu saja dengan kegiatan pembelajaran menempel kepingan bentukbentuk geometri yang dilakukan secara berkesinambungan akan membantu meningkatkan kreativitas anak serta dapat mengembangkan kemampuan kognitif anak.

Berdasarkan paparan kerangka teori dan tindakan yang akan dilakukan dapat diajukan hipotesis : Jika model pembelajaran menempel kepingan bentukbentuk geometri dirancang dengan baik, dapat membantu meningkatkan kreativitas anak Taman Kanak-Kanak Kelompok B-3 TK Negeri Pembina.

\section{Setting Penelitian}

Penelitian ini dilakukan pada Semester Genap Tahun Pelajaran 2014/2015 anak Kelompok B-3 di TK Negeri Pembina yang berjumlah 16 anak yang terdiri dari 8 anak laki-laki dan 8 anak perempuan. Rentan usia anak Kelompok B-3 adalah usia 6 tahun. Waktu yang digunakan untuk penelitian yang dimulai dari perencanaan, pelaksanaan, observasi dan refleksi serta penyusunan laporan dilaksanakan pada bulan Januari hingga April 2015.

\section{METODE PENELITIAN}

Penelitian ini menggunakan rancangan penelitian tindakan kelas sebagaimana yang mengikuti model yang dikembangkan oleh Kemmis dan Mc Taggart serta dijabarkan oleh Suharsimi
Arikunto dalam buku Penelitian Tindakan Kelas. Rancangan penelitian tindakan ini terdiri dari 2 siklus yang tiap siklusnya terdiri dari tahap perencanaan, tahap tindakan, tahad observasi dan tahap refleksi. Adapun penjelasannya sebagai berikut:

a. Tahap Perencanaan

Pada tahap perencanaan yang dilakukan peneliti adalah :

1) Menyusun Rencana Pelaksanaan Pembelajaran (RPP). RPP digunakan sebagai acuan peneliti dalam pelaksanaan pembelajaran. Penyusunan RPP berpedoman pada Rencana Kegiatan Harian (RKH) Taman Kanak-Kanak. Untuk kegiatan pembelajaran pertemuan pertama adalah menempel bentuk kereta api, pertemuan kedua menempel bentuk mobil, pertemuan ketiga menempel bentuk pesawat, pertemuan keempat menempel bentuk kapal, pertemuan kelima menempel bentuk balon udara, pertemuan keenam menempel bentuk roket.

2) Mempersiapkan segala kelengkapan untuk kegiatan pembelajaran yang meliputi alat peraga dan segala peralatan dan bahan yang diperlukan untuk kegiatan pembelajaran.

3) Menyusun lembar observasi dan lembar anekdote record yang berisi tentang sejauh mana perkembangan kemampuan kreativitas anak dalam mengikuti kegiatan pembelajaran dan mencatat segala kejadian saat pembelajaran.

4) Menyiapkan kelengkapan peralatan untuk mendokumentasikan kegiatan pembelajaran yang akan berlangsung, seperti kamera.

b. Tahap Tindakan

1). Kegiatan awal ( 07.15-08.00)

Kegiatan klasikal pertama di mulai dengan guru mengucapkan salam dan dijawab oleh anak-anak. Setelah itu guru memimpin anak- 
anak untuk berdoa sebelum belajar bersama-sama, kemudian dilanjutkan dengan menyanyikan lagu sesuai tema dilanjutkan penyampaian appersepsi. Setelah kegiatan selesai, dilanjutkan dengan membahas tema dan sub tema melalui kegiatan bercakapcakap. Selanjutnya dilaksanakan kegiatan klasikal awal.

2). Kegiatan inti (08.00-09.00)

Guru menjelaskan tentang kegiatan inti dengan model area. Setiap hari dibuka empat area belajar, dan guru menjelaskan tentang kegiatan inti yang dilaksanakan pada masingmasing area. Di area balok anakanak dijelaskan kegiatan menempel bentuk-bentuk geometri menjadi bentuk tertentu. Setelah selesai menjelaskan, guru memandu anakanak untuk mulai belajar sesuai minatnya. Setelah selesai hasil karyanya diserahkan kepada guru kelas, dan anak-anak bisa belajar di area berikutnya.

3). Kegiatan akhir (09.45-10.15)

Pada kegiatan akhir anak-anak belajar sesuai indikator dalam $\mathrm{RKH}$, dilanjutkan guru dan anakanak mengevaluasi kegiatan pembelajaran yang telah dilaksanakan dan menunjukkan hasil karya anak-anak untuk diapresiasi. Guru memotivasi anak-anak agar lebih baik lagi dalam belajar bersama sehingga hasil karyanya akan lebih bagus. Guru menyampaikan pesan-pesan, selanjutnya guru memimpin anakanak menyanyi lagu "Hari Sudah Siang" sebagai lagu penutup. Dilanjutkan berdoa sesudah belajar. Setelah selesai, guru mengucapkan salam penutup dan anak-anak pulang.

\section{c. Tahap Observasi}

Pengamatan dilaksanakan selama anak-anak mengikuti kegiatan pembelajaran, dimulai saat anak masuk kelas hingga anak pulang sekolah. Pada awal pertemuan, pada saat belajar mayoritas anak masih harus diberi contoh yang sudah jadi karena anak masih bingung kalau tanpa diberi contoh, anak masih bersikap meniru dan belum ada keberanian untuk menuangkan ide gagasnnya, masih dibantu guru dalam menempel, menyelesaikan tugas asal jadi tanpa mempertimbangkan kerapaian dan ketuntasan sehingga sikap bertanggungjawabnya masih belum maksimal, pada saat menilai dan mengapresiasi hasil karyanya bersikap pasif kurang berekspresi.

\section{d. Tahap Refleksi}

Pada tahap ini merupakan upaya untuk mengkaji yang telah dilakukan peneliti yaitu menganalisa hasil evaluasi pelaksanaan pembelajaran, untuk melakukan perbaikan terhadap kegiatan pembelajaran sebagai upaya untuk meningkatkan hasil belajar anak agar lebih baik. Berdasarlan hasil refleksi yang dilakukan peneliti pada tiap siklus, secara umum kegiatan pembelajaran menempel kepingan bentuk-bentuk geometri kelompok B-3 TK Negeri Pembina sudah mencapai target yang diharapkan peneliti. Bisa dipaparkan peningkatan kreativitas anak yang cukup meningkat sebagai hasil dari kegiatan pembelajaran pada tiap siklus

Untuk mengetahui sejauh mana efektifitas kegiatan pembelajaran, perlu dilakukan analisis data. Pada penelitian ini digunakan analisis diskriptif yaitu metode penelitian yang bersifat menggambarkan kenyataan sesuai data yang diperoleh dengan tujuan untuk mengetahui kemajuan kemampuan anak yang sesungguhnya dan untuk mengetahui kemampuan guru dalam mengelola kelas. Data yang diperoleh dalam penelitian ini berupa lembar observasi, catatan anekdote record. Data 
yang diperoleh dianalisis secara kualitatif dan dipaparkan dalam bentuk diskriptif.

Kegiatan penelitian ini dinyatakan berhasil dengan mengacu pada indikator pencapaian keberhasilan, yaitu :

1. Meningkatnya keberanian anak dalam menuangkan ide gagasannya dalam kegiatan menempel kepingan bentuk geometri.

2. Kemampuan anak untuk menyelesaikan tugas secara bertanggung jawab.

3. Bisa bersikap mandiri dalam menyelesaikan tugas.

4. Kerapiana anak dalam menyelesaikan tugas.

5. Bangga dan percaya diri dengan hasil karyanya

$$
\text { Kondisi awal kemampuan }
$$

kreativitas anak Kelompok B-3 TK Negeri Pembina dapat disampaikan bahwa berdasarkan hasil pengamatan ada $25 \%$ yang perkembangan kreativitasnya cukup baik (berkembang sesuai harapan), serta ada 75 yang belum baik (mulai berkembang) perkembangan kreativitasnya. Indikator cukup baik (berkembang sesuai harapan) diantaranya terlihat dari kemampuan anak dalam berkreasi dengan berbagai media, keberanian dalam menuangkan ide dan imajinasinya, bisa bertanggung jawab dalam menyelesaikan tugas, rapi dalam belajar, menyelesaikan tugas sendiri tanpa bantuan, memiliki kebanggaan atas hasil karyanya. Tetapi anak yang belum baik kreativitasnya (mulai berkembang), terlihat kurang berani menuangkan ide dan gagasannya, kurang tuntas menyelesaikan tugasnya, kurang rapi bekerja, masih dibantu menyelesaikan tugasnya, belum bisa mengapresiai hasil karyanya. Hasil perkembangan kreativitas anak dapat dilihat pada tabel 1 sebagai berikut:

Tabel 1. Hasil Siklus 1, 2 dan 3

\begin{tabular}{|c|c|c|c|c|}
\hline $\begin{array}{l}\mathbf{N} \\
\mathbf{0}\end{array}$ & $\begin{array}{l}\mathrm{Na} \\
\mathrm{ma} \\
\text { Ana }\end{array}$ & Siklus I & Siklus II & Siklus III \\
\hline
\end{tabular}

\begin{tabular}{|c|c|c|c|c|c|c|c|c|c|c|c|c|c|}
\hline & & & 2 & 3 & 4 & 1 & 2 & 3 & 4 & 1 & 2 & 3 & 4 \\
\hline & & & $\sqrt{ }$ & 1 & 1 & $\sqrt{ }$ & & $\sqrt{ }$ & $\sqrt{ }$ & & $\sqrt{ }$ & $\sqrt{ }$ & $v$ \\
\hline & & & 0 & o & $\circ$ & & ○ & $\sqrt{ }$ & $\circ$ & $\sqrt{ }$ & $\circ$ & $\sqrt{ }$ & 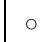 \\
\hline 3 & C & & $\circ$ & o & $\circ$ & 0 & 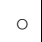 & $\sqrt{ }$ & $\circ$ & $\sqrt{ }$ & $\circ$ & $\sqrt{ }$ & o \\
\hline 4 & D & & $\circ$ & $\sqrt{ }$ & $\circ$ & $\sqrt{ }$ & $\sqrt{ }$ & $\checkmark$ & $\sqrt{ }$ & $\sqrt{ }$ & $\bullet$ & $\checkmark$ & $\sqrt{ }$ \\
\hline 5 & E & $y$ & $\circ$ & $\checkmark$ & $\circ$ & $\sqrt{ }$ & 0 & $\sqrt{ }$ & $\circ$ & • & $\sqrt{ }$ & $\sqrt{ }$ & $\sqrt{ }$ \\
\hline 6 & $\mathrm{~F}$ & $\sqrt{ }$ & $V$ & $\sqrt{ }$ & $\sqrt{ }$ & ○ & $\sqrt{ }$ & $\checkmark$ & $\sqrt{ }$ & $\sqrt{ }$ & • & $\sqrt{ }$ & $\sqrt{ }$ \\
\hline 7 & $\mathrm{G}$ & $\sqrt{ }$ & $\sqrt{ }$ & $\checkmark$ & $\circ$ & $\checkmark$ & $\sqrt{ }$ & $V$ & $\checkmark$ & • & $\sqrt{ }$ & $\sqrt{ }$ & $\sqrt{ }$ \\
\hline 8 & $\mathrm{H}$ & $\sqrt{ }$ & $\checkmark$ & $\sqrt{ }$ & $\checkmark$ & $\sqrt{ }$ & $\sqrt{ }$ & $\checkmark$ & $\checkmark$ & $\sqrt{ }$ & $\bullet$ & $\sqrt{ }$ & $\sqrt{ }$ \\
\hline 9 & I & ○ & $\circ$ & $\sqrt{ }$ & $\circ$ & $\checkmark$ & 0 & $V$ & $\sqrt{ }$ & $\sqrt{ }$ & $\sqrt{ }$ & $V$ & $\sqrt{ }$ \\
\hline $\begin{array}{l}1 \\
0\end{array}$ & $\mathrm{~J}$ & o & $\circ$ & $\circ$ & $\circ$ & $\checkmark$ & 0 & $\checkmark$ & $\circ$ & $\checkmark$ & $\sqrt{ }$ & $\sqrt{ }$ & $\sqrt{ }$ \\
\hline $\begin{array}{l}1 \\
1\end{array}$ & $\mathrm{~K}$ & $\circ$ & $\circ$ & $\sqrt{ }$ & $\circ$ & $\circ$ & $\circ$ & $\checkmark$ & $\circ$ & $\sqrt{ }$ & $\sqrt{ }$ & $\sqrt{ }$ & $\sqrt{ }$ \\
\hline 1 & $\mathrm{~L}$ & $\circ$ & $\circ$ & $\checkmark$ & $\circ$ & $\sqrt{ }$ & $\checkmark$ & $\checkmark$ & $\circ$ & • & $\sqrt{ }$ & $\sqrt{ }$ & $\sqrt{ }$ \\
\hline 1 & M & $\circ$ & $\circ$ & $\sqrt{ }$ & $\circ$ & $\sqrt{ }$ & $\circ$ & $\checkmark$ & $\circ$ & $\sqrt{ }$ & $\sqrt{ }$ & $\sqrt{ }$ & $\sqrt{ }$ \\
\hline $\begin{array}{l}1 \\
4\end{array}$ & $\mathrm{~N}$ & $\circ$ & 0 & $\sqrt{ }$ & $\circ$ & $\circ$ & $\circ$ & $\checkmark$ & $\circ$ & $\checkmark$ & $\sqrt{ }$ & $\sqrt{ }$ & $\sqrt{ }$ \\
\hline $\begin{array}{l}1 \\
5\end{array}$ & $\mathrm{O}$ & $\sqrt{ }$ & $\circ$ & $\checkmark$ & $\circ$ & $\checkmark$ & $\circ$ & $\checkmark$ & $\circ$ & $\sqrt{ }$ & $\sqrt{ }$ & $\sqrt{ }$ & $\circ$ \\
\hline $\begin{array}{l}1 \\
6\end{array}$ & $\mathrm{P}$ & $\circ$ & $\circ$ & $\sqrt{ }$ & $\sqrt{ }$ & $\checkmark$ & $\sqrt{ }$ & $\checkmark$ & $\checkmark$ & • & $\sqrt{ }$ & $\sqrt{ }$ & $\sqrt{ }$ \\
\hline & & $\begin{array}{l}4 \\
4 \\
\%\end{array}$ & $\begin{array}{l}2 \\
5 \\
\%\end{array}$ & $\begin{array}{l}8 \\
1 \\
\%\end{array}$ & $\begin{array}{l}2 \\
5 \\
\%\end{array}$ & $\begin{array}{l}6 \\
8 \\
\%\end{array}$ & $\begin{array}{l}4 \\
4 \\
\%\end{array}$ & \begin{tabular}{|l}
1 \\
0 \\
0 \\
$\%$
\end{tabular} & \begin{tabular}{|l|}
4 \\
4 \\
$\%$
\end{tabular} & $\begin{array}{l}7 \\
5 \\
\%\end{array}$ & $\begin{array}{l}6 \\
9 \\
\%\end{array}$ & $\begin{array}{l}1 \\
0 \\
0 \\
\%\end{array}$ & $\begin{array}{l}8 \\
2 \\
\%\end{array}$ \\
\hline & & $\begin{array}{l}5 \\
6 \\
\% \\
\end{array}$ & $\begin{array}{l}7 \\
5 \\
\% \\
\end{array}$ & $\begin{array}{l}1 \\
9 \\
\% \\
\end{array}$ & $\begin{array}{l}7 \\
5 \\
\% \\
\end{array}$ & $\begin{array}{l}3 \\
2 \\
\% \\
\end{array}$ & $\begin{array}{l}5 \\
6 \\
\% \\
\end{array}$ & \begin{tabular}{|l|}
0 \\
$\%$ \\
\end{tabular} & \begin{tabular}{|l|}
5 \\
6 \\
$\%$ \\
\end{tabular} & 0 & $\begin{array}{l}1 \\
2 \\
\% \\
\end{array}$ & $\begin{array}{l}0 \\
\% \\
\end{array}$ & \begin{tabular}{|l|l}
1 \\
8 \\
$\%$
\end{tabular} \\
\hline & & $\begin{array}{l}0 \\
\%\end{array}$ & $\begin{array}{l}0 \\
\%\end{array}$ & $\begin{array}{l}0 \\
\%\end{array}$ & $\begin{array}{l}0 \\
\%\end{array}$ & $\begin{array}{l}0 \\
\%\end{array}$ & $\begin{array}{l}0 \\
\%\end{array}$ & $\begin{array}{l}0 \\
\% \\
\end{array}$ & \begin{tabular}{|l|}
0 \\
$\%$ \\
\end{tabular} & $\begin{array}{l}2 \\
5 \\
\% \\
\end{array}$ & $\begin{array}{l}1 \\
9 \\
\%\end{array}$ & $\begin{array}{l}0 \\
\%\end{array}$ & $\begin{array}{l}0 \\
\%\end{array}$ \\
\hline
\end{tabular}

\section{Keterangan tabel 1:}

1: Tanggung jawab

2: Kerapian dan keberanian menuangkan ide

\section{3: Kemandirian}

4: Bangga pada hasil karyanya

-: Berkembang sangat baik

$\sqrt{ }$ : Berkembang sesuai harapan $\circ$ : Mulai berkembang

Berdasarkan data pada Tabel 1 diatas, dapat diketahui bahwa kreativitas anak dalam kegiatan menempel bentuk-bentuk geometri mengalami peningkatan.

Berdasarlan hasil refleksi yang dilakukan peneliti pada akhir siklus I, II dan III, secara umum kegiatan pembelajaran menempel kepingan bentukbentuk geometri kelompok B-3 TK Negeri Pembina mengalami peningkatan yang cukup baik. Pada akhir siklus I belum mencapai target yang diharapkan peneliti. Bisa dipaparkan peningkatan kreativitas anak pada siklus I ada $56 \%$ yang masuk kategori belum berkembang dan ada $44 \%$ 
yang masuk kategori berkembang sesuai harapan. Pada akhir siklus II dapat dipaparkan data capaiannya, ada 36\% yang masuk kategori belum berkembang, dan ada 64\% yang masuk kategori berkembang sesuai harapan. Pada akhir siklus III dapat dipaparkan datanya ada $7 \%$ yang masuk kategori belum berkembang dan ada $82 \%$ yang masuk kategori berkembang sesuai harapan dan ada $11 \%$ yang masuk kategori berkembang sangat baik. Berdasarlan hasil refleksi yang dilakukan peneliti pada akhir siklus III, secara umum kegiatan pembelajaran menempel kepingan bentukbentuk geometri kelompok B-3 TK Negeri Pembina telah mencapai target yang diharapkan peneliti.

\section{KESIMPULAN}

Berdasarkan hasil penelitian dan analisis data yang dilakukan peneliti dapat disimpulkan bahwa pembelajaran menempel kepingan bentuk - bentuk geometri mampu meningkatkan krativitas anak TK Kelompok B-3 TK Negeri Pembina. Kegiatan ini berdampak baik bagi peningkatan daya nalar dan daya cipta anak sehingga mampu mengembangkan kognitif anak ke arah kematangan berpikir, yang muaranya dapat meningkatkan daya kreativitas anak.

\section{DAFTAR PUSTAKA}

Elizabeth B. Hurlock. (1978). Perkembangan Anak. Jakarta : Penerbit Erlangga.

Siti Partini Suardiman. (2003). Metode Pengembangan Daya Pikir dan Daya Cipta untuk Anak Usia TK. Yogyakarta : UNY.

Suharsini Arikunto, dkk. (2006). Penelitian Tiindakan Kelas. Jakarta : Bumi Aksara.
Slamet Suyanto. (2003). Konsep Dasar Pendidikan Anak Usia Dini. Yogyakata : UNY.

File:///D:/Geometri\%20\%20Wikipedia $\% 2$ Obahasa $\% 20$ Indonesia, $\% 20$ ensiklopedia $\%$ 20bebas.html, diakses hari Sabtu tanggal 4 April 2015 jam 20.00 